\title{
Kajian Upaya Peningkatan Mutu Sosis Tradisional Timor (Budik)
}

\section{Study of Efforts to Improve the Quality of Traditional Sausage Timor (Budik)}

\author{
R. Pinto*, P. R. Kale, dan H. J. D. Lalel \\ Program Studi Ilmu Peternakan, Pascasarjana, Universitas Nusa Cendana \\ Jl. Adisucipto, Kupang, NTT 85001 \\ *E-mail: ona_rita@ymail.com
}

(Diterima: 26 Juni 2018; Disetujui: 9 Agustus 2018)

\begin{abstract}
ABSTRAK
Penelitian ini bertujuan untuk meningkatkan mutu sosis tradisional Timor (budik) berbahan dasar daging babi. Daging babi merupakan hasil ternak yang dikonsumsi masyarakat. Selain mengandung unsur-unsur gizi seperti karbohidrat, protein, vitamin, dan mineral, daging babi memiliki kelebihan yakni mengandung banyak thiamin (vitamin B1) yang diperlukan oleh tubuh untuk mencerna karbohidrat dan menunjang kerja sistem saraf. Penelitian ini menggunakan daging babi dengan lima (5) perlakuan, yakni: $\mathrm{P}_{0}$ : Darah 70\% + Lemak bagian abdominal 30\% sebagai kontrol $\mathrm{P}_{1}$ : Darah 70\% + Daging $30 \%, \mathrm{P}_{2}$ : Darah $40 \%+$ Lemak bagian abdominal $20 \%+$ Daging 40\%, $\mathrm{P}_{3}$ : Darah $35 \%+$ Lemak bagian abdominal 20\% + Daging $45 \%, \mathrm{P}_{4}$ : Darah 30\% + Lemak bagian Abdominal $20 \%+$ Daging 50\%. Parameter yang diuji dalam penelitian ini: kadar air, kadar abu, kadar protein, kadar lemak, serta warna, aroma, cita rasa dan tekstur. Rancangan yang digunakan adalah Rancangan Acak Lengkap (RAL). Data dianalisis dengan analysis of variance (ANOVA). Dilanjutkan dengan uji Duncan's. Data non parametrik hasil uji hedonik dianalisis dengan uji Kruskal-Wallis. Simpulan penelitian ini adalah Perbedaan konsentrasi campuran daging dalam masing-masing perlakuan sosis tradisional Timor (budik) memberikan perbedaan yang nyata terhadap kadar air, kadar abu, kadar lemak dan kadar protein, serta warna, aroma, cita rasa dan tekstur. Berdasarkan dari hasil yang diperoleh masing-masing perlakuan terbaik dari penambahan daging babi adalah perlakuan $\mathrm{P}_{1}$ dengan menggunakan darah $70 \%$ dan daging $30 \%$.
\end{abstract}

Kata kunci: babi, Budik, mutu sosis, sosis tradisional Timor

\begin{abstract}
This study aims to improve the quality of traditional Timor sausage (budik) based in pork. Pork meat is the product of livestock consumed by the community. Besides containing nutritional elements such as carbohydrates, proteins, vitamins and minerals pork has advantage of containing a lot of thiamin (vitamin B1) which is needed by the body to digest carbohydrates and support the work of the nervous system. This study used pork with five (5) treatments, namely: P0: Blood 70\% + abdominal fat 30\% as control, P1: Blood 70\% + Meat 30\%, P2: Blood 40\% + Abdominal fat 20\% + Meat 40\% P3: Blood 35\% + Abdominal fat 20\% + Meat 45\%, P4: Blood 30\% + Abdominal fat 20\% + Meat 50\%. Parameter tested in this study: water content, ash content, protein content, fat content, color, flavor, taste and texture. The design was used a complete randomized design (CRD). Data were analyzed with analysis of variance (ANOVA), Followed by Duncan's test. Non-parametric data from hedonic test result were analyzed by Kruskal-Wallis. This conclusion of studies is the difference in the concentration of mixed mixtures in each traditional Timor sausage treatment gave a significant difference in the Water content, Ash content, Protein content, Fat content, Color, Flavor, Taste and Texture tests. Based on the results obtained each of the best treatments from the addition of pork is treatment using p1: $0 \%$ blood and 30\% meat.
\end{abstract}

Keywords: Budik, pork, quality of sausage, traditional Timor Sausage 


\section{PENDAHULUAN}

Nusa Tenggara Timur (NTT) merupakan salah satu daerah yang memiliki keanekaragaman hayati yang sangat potensial bila digali dan dikembangkan. Potensi kekayaan budaya juga berpengaruh pada kekayaan seni masakan, sebab setiap daerah memiliki produk pengolahan makanan tradisional yang khas di antaranya sosis tradisional Timor (Budik) yang sejak dulu telah dibuat oleh masyarakat khususnya etnis Sabu, Rote dan Timor.

Makanan tradisional merupakan jenis makanan yang diolah dari bahan lokal dengan pengolahan yang bervariasi, memiliki ciri khas daerah setempat dan biasa dikonsumsi oleh masyarakat daerah tersebut. Beberapa makanan tradisional Nusa Tenggara Timur (NTT) diantaranya: daging asap khas Timor (se'i) biasanya terbuat dari daging sapi dan babi, susu goreng, jagung titi, dan sosis tradisional Timor (Budik).

Budik merupakan sejenis sosis yang dibuat dan dikonsumsi oleh beberapa etnis di NTT dan mirip sosis tradisional Bali (Urutan). Sosis tradisional ini dibuat dengan bahan dasar darah dan lemak bagian abdominal yang dicampur dengan bumbu lalu di masukkan ke dalam usus babi, sapi atau kambing. Budik ini merupakan salah satu bahan makanan khas yang digemari atau disukai oleh banyak kalangan di NTT. Sosis tradisional Bali (urutan) merupakan daging babi yang telah dipotong dengan ukuran kecil lalu ditambahkan garam serta campuran bumbu dan dimasukkan ke dalam selongsong yang berasal dari usus babi, berbagai bumbu rempah tersebut berfungsi sebagai pemberi aroma, cita rasa, pengawet, antioksidan dan anti mikroba (Shanti, 2013).

Darah dan lemak adalah bahan dasar yang biasa digunakan dalam pembuatan sosis tradisonal Timor (Budik) karena harganya yang relatif murah dan tersedia di beberapa pasar lokal di kota Kupang dan sekitarnya. Selama ini limbah darah di Rumah Pemotongan Hewan (RPH) dibuang percuma dan pemanfaatan tidak dilakukan secara maksimal, padahal pengolahan yang benar akan menghasilkan pakan ternak tambahan yang dapat dimanfaatkan oleh ternak, pembuatan pupuk kompos dan salah satunya adalah pembuatan sosis tradisonal Timor (Budik). Persentase darah babi di dalam tubuh ternak adalah sekitar 3,5-7\% dari total berat tubuhnya. Pembuangan limbah dari RPH berpotensi mencemari lingkungan karena mempengaruhi tingkat BOD (biochemical oxygen demand), lemak dan padatan terlarut (suspended solid) dari limbah cair (Jamilah, 2014).

Proses pembuatan sosis tradisonal Timor (Budik) banyak dilakukan secara sederhana dengan modal dan skala usaha kecil, penggunaan alat dan bahan baku masih sederhana, danpenanganan budik belum memenuhi mutu dan kualitas Standar Nasional Indonesia (SNI). Pembuatan sosis tradisional Timor (Budik) tersebut biasanya hanya untuk memenuhi kebutuhan pasar lokal dan belum banyak dikenal oleh kalangan masyarakat. Dalam proses pembuatan budik hanya digunakan darah dan lemak bagian abdominal tanpa adanya penambahan bahan lain serta pencampuran darah dan lemak tidak homogen sehingga pada saat dikonsumsi, konsumen cenderung memilih darahnya saja sedangkan lemaknya dibuang.

Berdasarkan SNI (Standar Nasional Indonesia) 01-3820-1995 sosis yang baik mengandung air maksimal $67 \%$, protein minimal $13 \%$, lemak maksimal $25 \%$, karbohidrat maksimal 8\%, serat kasar maksimal 25\%, dan abu maksimal $3 \%$. Syarief dan Halid (1993) menyatakan bahwa indikator mutu sosis akan berubah oleh adanya pengaruh dari faktor pengolahan seperti penggunaan bahan yang tidak higienis, pencampuran tidak tepat dan proporsi yang tidak berdasarkan SNI.

Kajian Upaya Peningkatan Mutu ... (Pinto et al.) 


\section{METODE}

\section{Materi}

Usus babi dibersihkan dengan air bersih untuk menghilangkan kotoran dan mukosa yang menempel pada usus babi. Lemak dan jaringan ikat pada daging dihilangkan. Daging yang telah siap dipotong kecil-kecil kemudian dimasukkan ke dalam alat penggiling (food processor) lalu masukan darah dan lemak yang telah disiapkan kemudian tambahkan $1.5 \%$ garam, digiling selama 1,5 menit. Adonan ditambah $1,5 \%$ bawang putih yang telah dipotong-potong kecil, $0,5 \%$ lada dan, kemudian digiling kembali selama 1,5 menit kemudian tambahkan es batu $20 \%$, kemudian digiling kembali selama 2 menit. Persentase bahan tambahan dihitung dari berat daging. Adonan kemudian dimasukkan ke dalam selongsong sosis (cashing). Sosis yang telah dimasukkan ke dalam selongsong dikukus selama 45 menit dengan suhu $\pm 80{ }^{\circ} \mathrm{C}$ modifikasi Ridwanto (2003).

\section{Metode}

Penelitian dengan desain eksperimen yang digunakan adalah Rancangan Acak Lengkap (RAL). Penelitian ini terdiri dari 5 perlakuan, di mana setiap perlakuan diulangi 5 kali, dan setiap ulanagan terdiri dari 5 percobaan sosis tradsisional Timor (budik).

Deskripsi perlakuan yang diamati dalam penelitian ini adalah sebagai berikut:

$\mathrm{P}_{0}$ : Darah $70 \%+$ Lemak bagian abdominal $30 \%$

$\mathrm{P}_{1}$ : Darah $70 \%+$ Daging $30 \%$

$\mathrm{P}_{2}$ : Darah $40 \%+$ Lemak bagian abdominal 20 $\%+$ Daging $40 \%$

$\mathrm{P}_{3}$ : Darah $35 \%+$ Lemak bagian abdominal $20 \%+$ Daging $45 \%$

$\mathrm{P}_{4}$ : Darah 30\% + Lemak bagian Abdominal $20 \%+$ Daging $50 \%$

\section{Parameter Pengamatan}

Analisis komposisi kimia meliputi; kadar air, kadar abu, kadar protein, kadar lemak (AOAC, 2005) dan uji organoleptik menggunakan metode skala hedonik
(Setyaningsih et al., 2010) Pengujian organoleptik dilakukan oleh 15 panelis tidak terlatih untuk melihat tingkat kesukaan panelis terhadap produk sosis tradisional Timor (budik). Skala kategori 7 poin dengan deskripsi sebagai berikut: sangat tidak suka (1), tidak suka (2), agak tidak suka (3), netral (4), agak suka (5), suka (6), sangat suka (7), mutu warna coklat gelap (1), coklat tua (2), coklat (3), coklat muda (4), coklat pucat (5), coklat kekuningan (6) dan kuning kecoklatan (7). Data dianalisis dengan menggunakan Analysis of Variance (ANOVA) dan selanjutnya dilakukan uji Duncan, apabila hasil analisis signifikan. Data non parametrik hasil uji hedonik dianalisis dengan uji KruskalWallis dilanjutkan dengan uji banding rataan ranking Mann-Whitney.

\section{HASIL DAN PEMBAHASAN}

\section{Kadar Air}

Komposisi kimia suatu bahan pangan merupakan faktor utama yang menjadi tolak ukur suatu produk pangan olahan, untuk layak tidaknya dikonsumsi dan dipasarkan. Susanto (2014) menjelaskan bahwa produk sosis dibagi dalam dua yaitu bentuk segar dan setelah dimasak/rebus. Lebih lanjut menjelaskan perebusan pada temperatur dan jangka waktu yang berbeda akan menghasilkan perbedaan kualitas daging baik kualitas fisik, kimia maupun organoleptik. Bagian-bagian daging babi yang bisa digunakan untuk membuat sosis babi adalah bahu, lulur, dan paha. Tiap bagian daging tersebut memiliki perbedaan sifat fisik dan kimia misalnya perbedaan warna, tekstur, dan komposisi kimia (Suseno et al., 2007).

Konsentrasi kadar air sosis tradisional Timor (budik) segar bervariasi antara $56,28 \%$ sampai $75,27 \%$ dengan rata-rata $61,84 \%$. Kadar air budik seluruh perlakuan menunjukkan perbedaan yang signifikan. Sunarlim dan Triyantini (2014) menyatakan bahwa kadar air sosis dipengaruhi oleh kandungan air dalam bahan pembuatan sosis. 
Tabel 1, Pengaruh perlakuan terhadap komposisi Kimia Sosis Tradisional Timor (Budik)

\begin{tabular}{lrrrrrrr}
\hline \multirow{2}{*}{ Parameter } & \multicolumn{9}{c}{ Perlakuan } & \multirow{2}{*}{ SEM } & \multirow{2}{*}{ P } \\
\cline { 2 - 5 } & \multicolumn{1}{c}{$\mathrm{P} 0$} & \multicolumn{1}{c}{$\mathrm{P} 1$} & \multicolumn{1}{c}{$\mathrm{P} 2$} & $\mathrm{P} 3$ & \multicolumn{1}{c}{ P4 } & & \\
\hline Kadar Air (\%) & $56,34^{\mathrm{a}}$ & $75,27^{\mathrm{c}}$ & $59,31^{\mathrm{a}}$ & $56,28^{\mathrm{a}}$ & $61,99^{\mathrm{b}}$ & 2,93 & 0,00 \\
Kadar Abu (\%) & $0,70^{\mathrm{a}}$ & $0,87^{\mathrm{bc}}$ & $0,88^{\mathrm{bc}}$ & $0,74^{\mathrm{ab}}$ & $0,94^{\mathrm{c}}$ & 0,08 & 0,01 \\
kadar Protein (\%) & $8,41^{\mathrm{a}}$ & $15,72^{\mathrm{b}}$ & $15,72^{\mathrm{b}}$ & $16,34^{\mathrm{b}}$ & $14,69^{\mathrm{b}}$ & 1,21 & 0,00 \\
kadar Lemak (\%) & $25,65^{\mathrm{c}}$ & $6,73^{\mathrm{a}}$ & $21,15^{\mathrm{b}}$ & $25,34^{\mathrm{c}}$ & $20,19^{\mathrm{b}}$ & 1,77 & 0,00 \\
\hline
\end{tabular}

Keterangan:

$\mathrm{SEM}=$ Standar error of mean, $\mathrm{P}=$ Probabilitas, Superskrip huruf kecil yang berbeda pada baris yang sama menunjukan perbedaan yang nyata

$\mathrm{P}_{0}$ : Darah $70 \%+$ Lemak bagian abdominal $30 \%=100 \%$

$\mathrm{P}_{1}$ : Darah $70 \%+$ Daging $30 \%$

$\mathrm{P}_{2}$ : Darah $40 \%+$ Lemak bagian abdominal $20 \%+$ Daging $40 \%$

$\mathrm{P}_{3}$ : Darah $35 \%+$ Lemak bagian abdominal $20 \%+$ Daging $45 \%$

$\mathrm{P}_{4}$ : Darah 30\% + Lemak bagian Abdominal $20 \%+$ Daging 50\%

Bahan yang digunakan dalam penelitian ini daging, lemak dan darah babi segar. Kandungan air darah segar sekitar $80 \%$ dan kandungan air tepung darah sekitar 16,5\% (Setiowati et al., 2014). Daging mengandung sekitar $75 \%$ air, serta lemak sekitar 2,5\% dan sangat bervariasi (Muchtadi et al., 2010). Daging babi mempunyai kadar air yang tinggi $( \pm 68-75 \%)$, kaya akan zat yang mengandung nitrogen dengan kompeksitas yang berbeda, mengandung sejumlah karbohidrat yang mudah untuk difermentasi, kaya akan mineral dan kelengkapan zat nutisi lainnya. (Soeparno, 2010). Hal ini perkuat oleh Usman (2009) bahwa dengan menambahkan daging dalam pembuatan sosis sebanyak $50 \%$ dari total adonan, sehingga mempengaruhi kadar air sosis yang dihasilkan. Prijambodo (2014) melaporkan bahwa kadar air sosis dengan penambahan kacang merah dan minyak kelapa sawit bervariasi antara 57,72\% hingga $64,88 \%$. Hasil ini juga lebih tinggi dibandingkan dengan hasil penelitian Fauziah (2014) mendapatkan rataaan kadar air sosis asap daging babi berkisar 55,58-58,39\%. Sementara berdasarkan syarat mutu SNI yaitu maksimal 67\% (Badan Standardisasi Nasional, 1995), maka kadar air sosis tradisional Timor (budik) hasil penelitian ini masih dalam kisaran kadar air sosis normal. Hal tersebut mengindikasikan bahwa keempat perlakuan memberikan pengaruh yang nyata terhadap kadar air sosis segar.

\section{Kadar Abu}

Kadar abu merupakan banyaknya mineral yang terkandungan dalam bahan atau produk yang dinyatakan dalam persen, berasal dari unsur mineral dan komposisi yang tidak teruapkan selama proses pengabuan. Kadar abu dianalisis menggunakan metode pengabuan cara kering. Tabel 1. diketahui bahwa sosis tradisional Timor (budik) dari penambahan proporsi daging yang berbeda secara signifikan terhadap konsentrasi kadar abu. Menurut (Soeparno, 2010), kadar abu berkaitan erat dengan kebersihan dan kemurnian bahan, sehingga persyaratan kadar abu sangat penting untuk mengetahui tingkat kebersihan dan kemurnian suatu bahan. Berdasarkan Tabel 1 menunjukkan rerata kadar abu sosis tradisional Timor (budik) dalam bentuk segar adalah 0,70-0,94\% sementara itu konsentrasi kadar abu dalam bahan kering berkisar antara 1,55-3,38\%. Data-data ini menggambarkan bahwa apa yang diperoleh penulis daalam penelitian ini masih dinyatakan memenuhi kriteria mutu sosis yakni maksimal 3\% berdasarkan SNI 01-3820-1995.

\section{Protein}

Rataan kadar protein hasil penelitian berkisar antara 8,41-16,34\% rata-rata 
(14,18\%). Hasil ini menjelaskan bahwa penambahan proporsi daging secara nyata meningkatkan konsentrasi protein budik. Kadar protein budik dari penambahan proporsi daging berbeda secara signifikan dengan kontrol $\mathrm{P}_{0}(70 \%$ darah dan $30 \%$ lemak abdominal) namun tidak pada perlakuan lainnya. Hal ini disebabkan karena kandungan protein daging babi lebih tinggi dari kandungan protein pada darah dan lemak abdominal. Lebih lanjut sumber utama protein pada budik diperoleh dari bahan bakunya yaitu daging babi itu sendiri, sedangkan kontribusi protein dari darah lemak bagian abdominal nilainya lebih kecil. Hal ini diperkuat oleh (Palandeng et al., 2016) bahwa, sumber utama protein pada sosis diperoleh dari bahan bakunya yaitu daging babi. Bervariasinya kadar protein pada sosis diduga berkaitan dengan sifat fisik sosis yaitu bahwa ada korelasi negatif antara susut masak dan kadar protein, dimana semakin besar nilai susut masak diikuti dengan menurunnya kadar protein (Martiana, 2015).

Penambahan lemak dan darah yang semakin banyak tidak terlalu berpengaruh pada kadar protein sosis. Pada daging babi mengandung protein sebesar 21,69\% sedangkan kadar protein pada darah sebesar $0,61 \%$ sehingga dengan semakin banyaknya penambahan darah akan mengurangi kadar protein pada sosis. Pemanasan di atas $60^{\circ} \mathrm{C}$ menyebabkan molekul nutrient seperti protein, karbohidrat, lemak, dan asam nukleat tidak stabil (Harijono dan Fibrianto, 2016). Penggunaan garam dan es pada tiap perlakuan memberikan kemampuan protein untuk mengikat air dan lemak. Penggilingan daging bersama dengan es dan garam akan menyebabkan ekstraksi protein yang lebih efisien dan mempengaruhi protein sosis (Harijono dan Fibrianto, 2016). Adanya perbedaan konsentrasi protein total diduga karena saat penambahan jumlah daging yang digunakan dengan porsi yang berbeda sehingga konsentrasi proteinnya bervariasi.

Standar bahwa kadar protein yang ditetapkan menurut SNI 01-3820-1995 tentang syarat mutu sosis daging yaitu minimal 12\%. Hasil yang diperoleh menunjukkan bahwa budik yang dihasilkan memenuhi standar tersebut.

\section{Lemak}

Rerata kadar lemak sosis yang dihasilkan adalah 6,73-25,65\%. Nilai rerata kadar lemak terkecil terdapat pada perlakuan $\mathrm{P}_{1}$ : Darah $70 \%$ dan daging 30\%, sedangkan tertinggi terdapat pada perlakuan $\mathrm{P}_{0}$ : Darah $70 \%$ + Lemak bagian abdominal 30\% dan $\mathrm{P}_{3}$ : Darah $40 \%$ + lemak bagian abdominal 20\% + daging $40 \%$. Konsentrasi kandungan lemak berbeda secara signifikan pada perlakuan darah $70 \%$ dan $30 \%$ daging, dengan perlakuan lainya. Hal ini disebabkan lemak yang terdapat pada darah dan daging yang relatif rendah, sehingga ketika konsentrasi lemak abdominal ditambahkan didalamnya cenderung meningkatkan kadar lemak sosis tradisional Timor (budik). Pernyataan ini sesuai dengan penelitian (Harijono dan Fibrianto, 2016) mengenai kandungan gizi bakso daging babi yang dibuat dengan penambahan konsentrasi daging babi yang berbeda dimana kadar lemak terendah pada formula daging dan lemak $(4 \%$ : $15 \%$ ) dan tertinggi pada formula daging dan lemak ( $0 \%: 45 \%)$. Menurut Soeparno (2005), bahwa kadar lemak mempunyai korelasi negatif dengan kadar protein dan air, yaitu apabila kadar protein dan airnya tinggi maka kadar lemaknya lebih rendah. Ditambahkan oleh Xiong dan Mikel (2001) bahwa, lemak berpengaruh pada sifat juiceness sosis, pembentuk tekstur yang kompak, serta pemberi rasa dan aroma yang khas, Lemak babi mengandung energi sebesar $630 \mathrm{kkal}$, protein 9,1 g, karbohidrat $1,1 \mathrm{~g}$, lemak $65 \mathrm{~g}$, kalsium $13 \mathrm{mg}$, fosfor $108 \mathrm{mg}$ dan zat besi 0 $\mathrm{mg}$. selain itu di dalam lemak juga terkandung vitamin A sebanyak 0 IU, vitamin B1 0,38 mg dan vitamin C $0 \mathrm{mg}$ dalam $100 \mathrm{~g}$ lemak.

Standar kadar lemak yang ditetapkan menurut SNI 01-3820-1995 tentang Syarat Mutu Sosis Daging yaitu maksimal 25\%. Hasil yang diperoleh menunjukkan bahwa budik yang dihasilkan memenuhi standar tersebut. 
Vol. 20 (3): 211-221

Tabel 2. Nilai modus warna, aroma, rasa dan tekstur sosis tradisional Timor (Budik)

\begin{tabular}{|c|c|c|c|c|c|c|c|}
\hline \multirow{2}{*}{ Parameter } & \multicolumn{5}{|c|}{ Perlakuan } & \multirow{2}{*}{ SEM } & \multirow{2}{*}{$\mathrm{P}$} \\
\hline & P0 & P1 & $\mathrm{P} 2$ & P3 & $\mathrm{P} 4$ & & \\
\hline Warna & 1 & 6 & 6 & 6 & 6 & 0,22 & 0,00 \\
\hline Aroma & 2 & 6 & 6 & 5 & 5 & 0,20 & 0,01 \\
\hline Rasa & 1 & 5 & 5 & 5 & 4 & 0,21 & 0,00 \\
\hline Tekstur & 1 & 7 & 5 & 4 & 4 & 0,22 & 0,00 \\
\hline
\end{tabular}

Keterangan:

$\mathrm{SEM}=$ Standar Error of Mean, $\mathrm{P}=$ Prababilitas

$\mathrm{P}_{0}$ : Darah $70 \%$ + Lemak bagian abdominal 30\%

$\mathrm{P}_{1}$ : Darah $70 \%+$ Daging $30 \%$

$\mathrm{P}_{2}$ : Darah $40 \%+$ Lemak bagian abdominal $20 \%+$ Daging $40 \%$

$\mathrm{P}_{3}$ : Darah $35 \%+$ Lemak bagian abdominal 20\%+ Daging $45 \%$

$\mathrm{P}_{4}$ : Darah 30\% + Lemak bagian Abdominal $20 \%+$ Daging 50\%.

\section{Karakteristik Sensori}

Sifat organoleptik merupakan sifat yang berhubungan dengan panca indera yaitu penglihatan, penciuman, pengecapan dan pendengaran. Faktor-faktor yang berhubungan dengan sifat organoleptik meliputi warna, aroma, cita rasa dan tekstur. Menurut Soekarto (1990), tujuan uji hedonik atau uji kesukaan yaitu untuk mengetahui respon panelis terhadap sifat mutu secara umum, misalnya rasa, aroma, warna, dan tekstur. Nilai organoleptik merupakan faktor utama yang mempengaruhi tingkat kesukaan konsumen terhadap suatu produk makanan, sehingga pada umumnya dijadikan acuan utama dalam mengkaji kualitas produk tertentu.

Nilai organoleptik sosis tradisional Timor (budik) dalam penelitian ini disajikan pada Tabel 2. Data dalam tabel tersebut menunjukkan bahwa terdapat pengaruh yang signifikan $(\mathrm{P}<0,05)$ terhadap parameter yang diukur (warna, aroma, rasa dan tekstur).

\section{Warna}

Warna merupakan salah satu faktor yang mempengaruhi makanan dilihat secara visual dan akan berpengaruh terhadap selera konsumen (Purwati, 2007). Sifat-sifat produk pangan yang paling menarik perhatian pada konsumen dan paling cepat pula memberikan kesan disukai atau tidak disukai adalah warna. Hasil analisis non parametrik Kruskall wallis menujukkan pencampuran daging, lemak, dan darah pada proporsi yang berbeda berpengaruh signifikan $(\mathrm{P}<0,05)$ terhadap parameter warna. Hasil ini menjelaskan bahwa nilai sensorik warna sosis tradisional Timor (budik) dipengaruhi oleh penambahan daging menyebabkan budik berwarna agak coklat kekuningan. Surbakti et al. (2016) menjelaskan bahwa sebuah preferensi panelis warna dapat dilihat dari intensitas kecerahan. Sosis yang memiliki kecerahan tinggi yang lebih disukai oleh panelis.

Faktor yang dapat mempengaruhi perubahan warna budik yaitu konsentrasi pigmen daging mioglobin yang ditambahkan didalammnya. Menurut Soeparno (2009), tipe mioglobulin, status kimia mioglobulin, dan kondisi kimia serta fisik komponen lain dalam daging mempunyai peranan besar dalam menentukan warna daging. Ada tiga macam mioglobin yang memberikan warna yang berbeda yaitu pada jaringan otot yang masih hidup, mioglobin dalam bentuk tereduksi dengan warna merah keunguan, mioglobin ini seimbang dengan mioglobin yang mengalami kontak dengan oksigen, oximioglobin yang berwarna merah cerah.

Darah adalah salah satu produk sampingan hewan yang paling penting dan mempunyai biologi yang tinggi (Chowdhury et al., 2015). Persentase darah digunakan 
secara terbatas karena memiliki cacat seperti bau yang menyinggung (Dàvila et al., 2007), warna coklat tua produk akhir karena mengandung darah sekitar $14 \%$ hemoglobin, terutama warna gelap adalah masalah kualitas sensorik utama saat darah ditambahkan ke produk daging (Chowdhury et al., 2015). Warna budik cokelat kekuningan dihasilkan dari proses pemanasan atau perebusan adonan budik. Selama pemanasan warna daging akan berubah secara bertahap dari merah muda menjadi lebih coklat. Perubahan warna tersebut akibat dari jumlah pigmen myoglobin yang teroksidasi menjadi metmyoglobin dan polimerisasi protein (Putri, 2009). Penggunaan daging babi prerigor juga akan mempengaruhi warna sosis yang dihasilkan. Hatta (2011) menyatakan bahwa pengunaan daging babi postrigor akan menghasilkan warna sosis lebih putih bila dibandingkan dengan menggunakan daging pre-rigor. Warna sosis dengan penambahan daging babi sama dengan warna sosisyaitu cokelat kekuningan. Ningsih et al., (2009) dan Wibowo, (2006) menambahkan bahwa kriteria mutu sensori sosis daging dari segi atribut warna yaitu cokelat muda cerah atausedikit agak kemerahan dan atau cokelat. Kualitas warna sosis tradisional Timor yang dihasilkan dengan menggunakan proporsidarah, lemak dan daging yang berbeda telah memenuhi syarat Standar Nasional Indonesia (SNI) 013820- 1995.

\section{Aroma}

Aroma suatu produk olahan adalah sensasi yang kompleks dan saling terkait dengan bau, rasa, dan tekstur. Menurut Soekarto (1985) aroma disebut juga pencicipan jarak jauh karena manusia dapat mengenal enaknya makanan yang belum terlihat hanya dengan mencium aromanya dari jarak jauh, manusia dapat mencium bau yang keluar dari makanan karena adanya sel-sel epitel alfaktori di bagian dinding atas rongga hidung yang peka terhadap komponen bau.

Aroma budik yang dihasilkan ketika adanya bahan tambahan lainnya di dalammnya menghasilkan aroma bumbu dan daging babi. Sementara aroma yang diperoleh dari budik perlakuan kontrol $(\mathrm{P} 0=$ proporsi tradisional) menghasilkan budik beraroma darah babi (bau amis) (Skor 2). Fenomena ini menggambarkan bahwa untuk meningkatkan nilai tambah dari suatu produk budik maka diperlukan bahan tambahan lainnya yaitu daging. Dimana daging akan menghasilkan aroma yang memikat selerah bagi yang akan mengkonsumsinya. Menurut Wibowo (2006) mutu sensori sosis memiliki bau khas daging segar rebus dominan, tanpa bau tengik, masam, basi atau busuk, danbau bumbu cukup tajam. Hal tersebut menerangkan bahwa aroma sosis sangat dipengaruhi oleh jumlah daging dan bahan lain yang digunakan.

Perbedaan aroma budik hasil penelitian ini diduga akibat kandungan lemak yang terdapat pada daging babi dalam bentuk trigliserida dan senyawa kompleks fosfolipid. Keberadaan lemak di dalam daging babi menyebabkan terjadi perbedaan rasa (flavour) dan aroma pada daging serta palatabilitas. Sudarmadji et al. (1989) menegaskan dalam teknologi makanan, lemak dan minyak memegang peranan yang penting. Lemak dan minyak memberikan rasa gurih yang spesifik yang berbeda dari gurihnya protein, selain juga memberi aroma yang spesifik. Sutejo dan Damayanti (2002) menjelaskan dengan penambahan rempah-rempah yang digunakan dalam proses olahan daging dapat menghilangkan bau anyir. Berdasarkan syarat mutu SNI sosis, kualitas bau sosis tradisional Timor masih sesuai dengan syarat mutu Standar Nasional Indonesia (SNI) sosis 013820-1995, yaitu berbau normal (khas Sosis Daging). Dari penelitian-penelitian yang dilakukan diperoleh bahwa perubahan aroma bahan dapat mempengaruhi bau beraroma yang timbul karena dapat mempengaruhi kecepatan timbulnya rangsangan terhadap sel reseptor olfaktori dan kelenjar air liur (Setyaningsih, 2010).

\section{Cita Rasa}

Cita rasa sendiri didefinisikan sebagai rangsangan yang ditimbulkan oleh bahan yang dimakan, terutama dirasakan oleh indera 
pengecap dan pembau, juga rangsangan lain seperti perabaan dan penerimaan derajat panas dimulut (Susanti, 2001). Tingkat kesukaan panelis terhadap budik secara signifikan dipengaruhi proporsi bahan tambahan yang di campur di dalamnya (Tabel 2). Dengan kata lain, menambahkan daging didalam proses pengolahan budik menghasilkan citarasa terggolong suka dan masih dapat diterima oleh panelis, di mana dengan tidak adanya penambahan daging di dalam proses pembuatan budik maka mayoritas panelis, memberikan skor 1 (sangat terasa darah berlemak). Menurut (Prayitno et al., 2009), sebagian besar responden menyukai sosis dengan rasa daging yang kuat. Hasil penelitian menunjukkan bahwa nilai uji organoleptik cita rasa budik, lebih rendah pada perlakuan $\mathrm{P}_{0}$ dibandingkan dengan perlakuan lainnya. Hal ini disebabkan adanya penambahan daging akan mendominasi rasa dan pada sosis dan mengurangi rasa dari lemak dalam sosis tersebut (Palandeng et al., 2016). Menurut Forrest et al. (1975) penambahan bahan penyedap dan bumbu dapat menambah atau meningkatkan citarasa pada sosis. Rasa memegang peranan penting dari keberadaan suatu produk dalam hal ini terkait dengan selera konsumen. Rasa merupakan kualitas sensori daging yang berkaitan dengan indera perasa. Salah satu faktor yang menentukan suatu produk diterima atau tidak oleh konsumen adalah dari segi rasa (Widodo, 2008).

\section{Tekstur}

Tekstur merupakan sifat sensoris daging yang berkaitan dengan tingkat kehalusan dari daging. Hasil penelitian menunjukan bahwa skor tekstur sosis tradisional Timor (budik) berbeda sangat nyata $(\mathrm{P}<0,01)$. Skor tekstur berkisar antara skor 1 (sangat lembek tidak Kompak) sampai 7 (sangat Padat dan Kompak). Tekstur yang lembek tidak kompak diduga disebabkan bahan campuran dimana hanya terdiri dari darah dan lemak abdominal, sementara penampakan tekstur sangat padat dan kompak dikarenakan bahan campuran terdiri dari darah $70 \%$ dan daging $30 \%$. Hasil ini mendukung pernyataan Susilo (2003) menjelasakan perbedaan tekstur disebabkan oleh beberapa hal, yakni perbedaan karena perbedaan komposisi bahan campuran, perbedaan tingkat kematangan, perbedaan karena panen, dan penanganan pasca panen, serta perbedaan yang disebabkan oleh metode pengolahannya.

Darah adalah produk sampingan yang penting dalam industri daging dengan banyak kegunaan dan potensi karena itu beberapa peneliti melaporkan bahwa darah digunakan sebagai pengikat dan bahan aditif pada sosis sehingga mutu sensori sosis darah memiliki tekstur kompak, elastis, kenyal tapi tidak liat atau membal, tidak lembek, tidak basah berair dan tidak rapuh (Dàvila et al., 2007).

\section{KESIMPULAN}

Berdasarkan hasil penelitian yang diperoleh dapat disimpulkan:

1. Sosis tradisional Timor (budik) memiliki nilai gizi rata-rata sebagai berikut: kandungan air 56,34\%; kadar abu 0,70\%; kadar protein $8,41 \%$ dan kadar lemak sebesar 25,65\%. Secara organoleptik budik tradisional ini tidak disukai oleh mayoritas panelis dan hal ini tercermin dari nilai yang diberikan hanya 1-2 untuk seluruh variable yang dinilai yaitu variabel warna, aroma, rasa dan tekstur.

2. Modifikasi komposisi bahan baku yang digunakan untuk membuat budik serta proses pembuatannya secara nyata meningkatkan mutu sosis tradisional ini untuk seluruh variabel yang dinilai. Kadar proteinmeningkat kurang lebih 2 kali lipat menjadi $14,69 \%$ hingga $16,34 \%$; Kadar abu meningkat 0,74-0,94\%; sedangkan kandungan lemak menurun menjadi 25,34$6,73 \%$. Kualitas organoleptik budik hasil modifikasi juga meningkat secara nyata di mana seluruh panelis memberikan skore penilaian 6 untuk warna, 5-6 untuk aroma dan 4-5 untuk rasa sedangkan tekstur mendapat nilai 4-7. 
3. Berdasarkan hasil tersebut di atas dilihat dari semua variabel yang diukur maka dapat disimpulkan bahwa budik modifikasi yang terbaik adalah budik dengan komposoisi Darah 70\% + Daging 30\% (P1).

\section{DAFTAR PUSTAKA}

Association of Official Analitical Chemistry (AOAC). 2005. Official Methods of Analysis. 16th edition. Arlington, Virginia: Association of Official Analitical Chemist Inc.

Dàvila, E., Parés, D., Cuvelier, G. and Perla Relkin, P. 2007. Heat-induced gelation of porcine blood plasma proteinsas affect by pH. Meat Sci. 76, 216-225.

Dewan Standardisasi Nasional. 1995. Sosis Daging. 01-3820-1995. Standar Nasional Indonesia, Jakarta.

Dewan Standardisasi Nasional. 1995. Bahan Tambahan Makanan. 01-0222-1995. Standar Nasional Indonesia, Jakarta.

Fauziah dan A. Muchtar. 2014. Pengasapan Daging Menggunakan Lemari Asap Skala Rumah Tangga. Jurnal Peternakan Indonesia. 17 (1) : 1 (14).

Feriana C. Palandeng, Lucia C. Mandey. Frans Lumoindong. 2016. Karateristik Fisiko-Kimia dan Sensori Sosis Ayam Petelur Afkir yang Difortifikasi dengan Pasta dari Wortel (Daucus Carota L). Jurnal Ilmu dan Teknologi Pangan. vol.4 (2).

Forrest, J.C., Aberle, E.D., Hedrick, H.B., Judge, M.D. and Merkel, R.A.,1975. Principles Of Meat Science. W.H. Freeman and Company. Ilmu Pangan. $\mathrm{H}$.

Hatta, M. 2011. Pengaruh level dan waktu penambahan fosfat (sodium tripolifosfat/ STTP) terhadap kualitas bakso. JurnalAgrisistem, 7 (2): 87-95.

Harijono, T. E. dan E. W. K. Fibrianto. 2016. Kimia dan Fisik Pangan. Cetakan pertama Bumi Aksara : Jakarta.
Hayyuningsih, D. R. W., D. Sarbini dan P. Kurnia. 2009. Perbedaan kandungan proteinzat besi dan daya terima padapembuatan bakso dengan perbandingan jamur tiram (PleurotusSp.) dan daging sapi yang berbeda.Jurnal kesehatan, 2 (1): 1-10.

Jamilah. 2014. Pemanfaatan Darah dari Limbah RPH. Diakses pada 2 Maret 2018.

Martiana, P. A. 2015. Eksperimen Pembuatan Sosis Ikan Lele Dumbo (Clarias gariepinus) dengan penambahan Wortel. Skripsi. Fakultas Teknik Universitas Negeri Semarang. Semarang.

Muchtadi, T. R., Sugiyono dan Ayustaningwarno, F. 2010. Ilmu Pengetahuan Bahan Pangan Alfabeta: Bandung.

Purwati, E. 2007. Petunjuk Analisis Sifat Fisik dan Kimia Pangan. J. Litbang Pertanian.

Putri, A. F. E. 2009. Sifat fisik dan organoleptiksosis babi pada lamapostmortem yang berbeda denganpenambahan karagenan. Skripsi Fakultas Peternakan Institut Pertanian Bogor, Bogor.

Prastini,A.I. Widjanarko. 2015. Pembuatan Sosis Ayam Menggunakan Gel Parong (Amorphophallus mueleri Blume) Sebagai Bahan Pengikat Terhadap Karakteristik Sosis. Jurusan Teknologi Hasil Pertanian, FTP Universitas Brawijaya Malang Jl. Veteran, Malang.

Prijambodo, O. M. 2014. Karakeristik Fisikokimia dan organoleptik Sosis Ayam Dengan Proporsi Kacang Merah Kukus dan Minyak Kelapa Sawit.Fakultas Teknologi Pertanian. Universita Katolitk Widya Mandala Surabaya.

Prawirosentono, S. 2004. Filosofi Baru Tentang Manajemen Mutu Terpadu, Rineka Cipta. Jakarta. 
Prayitno, A. H., F. Miskiyah., A.V. Rachmawati., T.M. Baghaskoro., B.P. Gunawan, dan Soeparno. 2009. Karakteristik Sosis Dengan Fortifikasi $\beta$-Caroten Dari Labu Kuning (Cucurbita moschata). Jurnal. Buletin Peternakan Vol. 33(2): 111-118, Juni 2009.

Ridwanto, 2003. Evaluasi Nilai Gizi dan Karakteristik Program Study Teknologi Hasil Ternak, Fakultas Peternakan Institut Pertanian Bogor.

Chowdhury, S., M. Hazarika, D. R. Nath and J. D. Mahanta. 2015. Physicochemical and sensory qualities of pork sausage incorporated with blood. College of Veterinary Science, Assam Agriculture University, Khanapara Campus, Guwahati-781 022, India. Volume 34.

Setyaningsih, D. A. Apriyantono., Sari.2010. Analisis Sensori untuk Industri Pangan dan Agro. Penerbit IPB Press. Bogor

Setiowati S., E.Sudjarwo and A.A Hamiyanti. 2014. The effect of blood meal addition in the feed to carcass and giblet percentages of quail.

Shanti. 2013. Sosis Tradisional Masyarakat Bali. http://santhiserad.com/2013/06/ urutan-sosis-tradisional-masyarakatBali. diakses 29 Juni 2017.

Sumardji., S. Hariyono dan B. Suhardi. 1889. Prosedur Analisis Bahan Makanan dan Pertanian. Liberty. Yogyakarta.

Sunarlim, R. dan Triyantini. 1992. Penggunaan berbagai konsentrasi $\mathrm{NaCl}$ dan jenis daging terhadap mutu bakso. Prosiding. Balai Besar Penelitian dan PengembanganPasca Panen dan Pertanian. Jakarta.

Susanti, I. 2001. Studi Keamanan Pangan Dan Karakteristik Sifat Fisik Dan Kimia Serta Organoleptik 9 Merek Sosis Sapi Yang Beredar Di Pasar Swalayan Kodya Malang (Kajian Kadar Nitrit Dan Jenis Pewarna Sintetis). Skripsi. Teknologi Hasil Pertanian. Fakultas Teknologi Pertanian. UNIBRAW.
Sutejo, A. dan W. Damayanti. 2002. Sistem Produksi dan Pengawasn Mutu Kerupuk Kaki Ayam. PT Trubus. Agrisarana, Surabaya.

Susanto, E dan Wardoyo. 2014. Pengaruh Substitusi Daging Babi terhadap Karakteristik Asam Lemak Sosis. Jurnal Ilmiah Fakultas Peternakan Universitas Islam Lamongan.

Susilo, A. 2003. Karakteristik Fisik, Ultrastruktur, dan Komposisi Kimia Daging Beberapa Bangsa ternak. Tesis. Fakultas Peternakan Program Pascasarjana. Universitas Gadjah Mada. Yogyakarta.

Soekarto, S. 1985. Penilaian Organoleptik Pangan. Jakarta.

Soekarto, S. 1990. Dasar-dasar Pengawasan dan Standarisasi Mutu Pangan. Bogor: IPB-Press.

Soeparno. 2010. Ilmu dan Teknologi Daging.Gajah Mada University Press. Yogyakarta.

Soeparno. 2009. Ilmu dan Teknologi Daging. Gadjah Mada University Press. Yogyakarta.

Soeparno. 2005. Ilmu dan Teknologi Daging. Gadjah Mada University Press. Yogyakarta.

Syarief, R. dan Halid. 1993. Teknologi Penyimpanan Pangan. Arcan Jakarta.

Suseno,T. I. P., S. Surjoseputro dan I. M. Fransisca. 2007. Pengaruh Penambahan Jenis Bagian Daging Babi Terhadap Sifat Fisikomiawi Pork Sosis. Teknologi Pangan dan Gizi.

Teti, E. Harijono dan E. W. K. Fibrianto. 2016. Kimia dan Fisik Pangan. Cetakan pertama ditebitkan oleh Bumi Aksara Jl. Sawo Raya No. 18 Jakarta 13220.

Usman. 2009. Studi pembuatan sosis berbasis jamur merang (Volvariellavolvaceae). Skripsi Fakultas Teknologi Pertanian Institut Pertanian Bogor, Bogor.

Wibowo, S. 2006. Pembuatan sosis babi Penebar Swadaya. Jakarta.

Kajian Upaya Peningkatan Mutu ... (Pinto et al.) 
Widodo, S. A. 2008. Karakteristik Sosis Ikan Kurisi (Nemipterus nematophorus) Dengan Penambahan Isolat Protein Kedelai dan Karagenan Pada Penyimpanan Suhu Chilling dan Freezing. Skripsi. Fakultas Perikanan dan Ilmu Kelautan, Istitut Pertanian Bogor. Bogor

Xiong, Y. L. and W. B. Mikel. 2001. Meat and Meat Products, Dalam: Hui, Y. H., W. K. Nip, R. W. Rogers, dan O. A. Young.
Meat Science and Applications. Marcel Dekker Inc., USA.

Zurriyati. Y. 2011. Palatabilitas Bakso Dan Sosis Sapi Asal Daging Segar, Daging Beku Dan Produk Komersial. Balai Pengkajian Teknologi Pertanian (BPTP) Riau J1. Kaharuddin Nasution KM 10 Pekanbaru E-mail: Vol 8 No 2 (4957). 